The use of deuterium as an indicator was discussed by Prof. H. S. Raper and Dr. W. E. van Heyningen. The former referred to the work of Cavanagh and Raper, in which fats labelled with deuterium were fed to animals and a study made of the rate of formation of the deuterium labelled lipins in the liver and kidney; the latter gave an account of the work of Schoenheimer and Rittenberg et al. on deuterium as an indicator in the study of intermediary metabolism, and referred especially to the uses and limitations of the method.

The use of heavy oxygen as an indicator was discussed by Dr. J. N. E. Day. He referred to the work of Aten and Hevesy, who examined the possibility of exchange of oxygen in sulphate, with other oxygen atoms present in the body, by injecting heavy sodium sulphate into rabbits, and concluded that there was little or no exchange. Reference was also made to the work of Day and Sheel on the use of heavy oxygen in animal respiration, in which the heaviness of the expired carbon dioxide was determined.

Radioactive sodium was dealt with by Dr. B. G. Maegraith, who mentioned experiments in which active sodium chloride had been injected into rabbits, and the distribution of the active sodium investigated. He suggested that this might be used to estimate the extracellular fluid content of the rabbit.

Dr. W. D. Armstrong described experiments dealing with the exchange of phosphorus of the enamel of teeth and the blood using radioactive phosphorus. A very slow exchange was noticed, indicating, not the formation of new molecules, but exchange of phosphate between enamel and blood. Mr. C. H. Collie referred to work of Collie and Morgan showing that radioactive sulphur can be used as an indicator.

Dr. D. Roaf described a method of producing radioactive phosphorus by irradiation of tricresyl phosphate with slow neutrons.

\title{
Obituary Notices
}

\section{Prof. Franz Werner}

Pro ROF. FRANZ WERNER'S death, which took place in Vienna on February 18 after a short illness at the age of seventy-two years, came as a shock to his numerous herpetological friends and colleagues the world over. Born in 1867, Franz obtained his doctorate at the University of Vienna in 1890 at the early age of twenty-three years, was appointed assistant in the First Zoological Institute of the University, later rising to be professor there, and had a distinguished record as a teacher until 1933, when he became emeritus professor. For more than fifty years, almost up to his death, he was zealously engaged in zoological researches, being in the foremost ranks of European herpetologists and a recipient of many honours. He was a corresponding member of the Vienna Academy of Sciences, an honorary doctor of the University of Athens, an honorary member of the American Society of Ichthyologists and Herpetologists, and a member of numerous other scientific societies.

Prof. Werner was a prolific writer, having more than a hundred papers, including some voluminous works, to his credit, the list including not only papers on Amphibia and Reptilia, in which he was principally interested, but also titles on Orthoptera and scorpions. Interested at first in morphological problems, he became more and more devoted to faunal exploration and herpetological taxonomy as the years went by. He undertook many travels for the sake of such study, and made valuable contributions to our knowledge of the fauna of Greece and the Egean Islands (1902, 1912, 1927, 1930, 1933, 1935, 1936, 1937), Algeria and Morocco (1914, 1929, 1931), Asia Minor
(1902, 1903, 1905, 1929), Persia (1903, 1917, 1929, 1936), South and West Africa (1902, 1913, 1915), Anglo-Egyptian Sudan (1914, 1919, 1924), Guatemala (1903), the Andes (1916), China (1903, 1924), etc. His contributions on Chamæleontidæ (1911), Eublepharidæ, Uroplatidæ, Pygopodidæ (1912) and Reptilia Loricata (1933) in "Das Tierreich" ; on Amphibia and Reptilia in Brehm's "Tierleben" (1913); and on Amphibia (excluding Anura) in Kükenthal's "Handbuch der Zoologie" (1930-31) are models of deep learning and lucid expression, and will make him familiar to younger generations of herpetologists even when the charm of his personality is long forgotten.

He was a patient, enthusiastic and indefatigable worker for herpetology.

\section{B. C. MAHENDRA.}

\section{Dr. E. H. Hankin}

The death on March 29 of Ernest Hanbury Hankin at the age of seventy-four years removes one who in the early days of the development of bacteriology did much to forward its practical applications. The son of a clergyman, he was educated at Merchant Taylors' School, at University College, London, and at St. John's College, Cambridge, of which he was a scholar and later a fellow, obtaining the M.A. and Sc.D. degrees. He also studied at St. Bartholomew's Hospital for a time, but did not proceed to a medical qualification, and worked in Koch's laboratory in Berlin and in the Pasteur Institute, Paris. He then accepted an appointment as chemical examiner, analyst and bacteriologist to the North-West Provinces and Oudh, India, and spent his professional 